\title{
PERAN PEMIMPIN DALAM MEMOTIVASI \\ PEGAWAI TATA USAHA (STUDI PADA MTS NEGERI KOTO BARU, KABUPATEN SOLOK)
}

\author{
Amri \\ Pegawai Tata Usaha MTs Negeri Koto Baru, Kabupaten Solok
}

\begin{abstract}
The aim of this qualitative research was to describe the role of principal in motivating the administration officers, and to understand the problems related to the policy of principal MTs Negeri Koto Baru Solok. The interview and documentation were used as instruments on collecting data. The results showed that the role of principal in motivating administration officers by upgrading personal relationship and understanding personal character. While the problems were the administration officers had different caharacter and different mindset.
\end{abstract}

Keywords: Leader, Motivation, Aministration Officer, MTs Negeri Koto Baru, Kabupaten Solok.

\section{PENDAHULUAN}

Era globalisasi sebagai era tanpa batas, salah satunya ditandai dengan persaingan dunia usaha yang semakin ketat. Setiap Madrasah berusaha memenangkan persaingan dengan mendayagunakan segenap sumber daya yang dimiliki. Salah satu sumber daya itu adalah Sumber Daya Manusia (SDM). SDM merupakan sumber daya yang memegang peran sentral di Madrasah. Hal ini karena peralatan secanggih apapun tidak akan berarti tanpa adanya SDM yang mampu dimanfaatkan demi mendukung pencapaian tujuan Madrasah. Mengingat pentingnya peran SDM, maka merupakan harapan setiap Madrasah memiliki manusiamanusia berkualitas yang akan memudahkan mereka dalam mencapai tujuannya. Namun, kualitas tinggi (kemampuan) saja belum cukup untuk melahirkan kinerja yang baik, karena kinerja merupakan fungsi dari kemampuan dan motivasi Pegawai tata usaha. Dengan asumsi bahwa kemampuan pegawai Tata Usaha telah memadai, maka Madrasah harus lebih memperhatikan motivasi pegawai Tata Usaha.

Penelitian ini dilakukan pada MTs Negeri Koto Baru Solok, dengan alasan sekolah tersebut telah mampu menjadi pesaing dari Madrasah sejenisnya yang telah lebih dulu berdiri. Dalam mencapai kemajuan yang cukup cepat, tentunya tidak lepas dari peran seorang pemimpin dalam memotivasi pegawai Tata Usaha sehingga dapat memotivasi kerja pegawai Tata Usaha untuk mencapai tujuan yang diharapkan.

Tujuan dari penelitian ini adalah untuk mengetahui peran pemimpin dalam memotivasi pegawai Tata Usaha pada MTs Negeri Koto Baru, Solok; untuk mengetahui kendala yang dihadapi oleh pemimpin dalam memotivasi pegawai Tata Usaha; dan untuk 
mengetahui usaha pemimpin mengatasi permasalahan dalam memotivasi pegawai Tata Usaha.

\section{KEPEMIMPINAN}

Bicara tentang pemimpin tak lepas dari kata kepemimpinan itu sendiri, begitu pula sebaliknya. Kepemimpinan adalah aktivitas mempengaruhi yang dilakukan oleh pemimpin kepada orang yang dipimpinnya, atau yang lazim disebut bawahan. Hal ini sesuai dengan yang diungkapkan Sule dan Saefullah (2005: 225) yang menyebutkan bahwa kepemimpinan dapat diartikan sebagai "proses mempengaruhi dan mengarahkan pegawai dalam melakukan pekerjaan yang telah ditugaskan kepada mereka". Mohyi (2006: 175) mendefinisikan kepemimpinan sebagai "kegiatan mempengaruhi, mengorganisir, menggerakan, mengarahkan atau mempengaruhi orang lain (bawahan) untuk melaksanakan sesuatu dalam rangka mencapai tujuan". Definisi Mohyi memandang beberapa unsur mengenai proses mempengaruhi yakni menyangkut keterlibatan orang lain atau kelompok orang dalam mencapai tujuan, adanya faktor tertentu pada pemimpin sehingga rang lain bersedia dipengaruhi, dan adanya usaha bersama dan menyerahkan berbagai sumber. Nawawi (2003: 46-57) menjabarkan beberapa fungsi pemimpin antara lain 1) pengambil Keputusan; 2) fungsi Instruktif; 3) fungsi konsulatif; 4) fungsi partisipatif; dan 5) fungsi delegatif.

\section{MOTIVASI}

Hersey dan Blanchard (2008:16) menyebutkan bahwa "motif adalah ikhwal "mengapanya" perilaku". Motif ada kalanya diartikan sebagai kebutuhan, keinginan, dorongan dalam diri seseorang. Individu pada karyawan adalah berbeda-beda. Mereka tidak hanya berbeda dalam hal kemampuannya melakukan sesuatu tetapi juga dalam hal kemauan mereka, atau motivasi mereka melakukan hal itu. Motivasi seseorang bergantung pada kuat lemahnya motif. Motif-motif yang jelas, tegas, dan kuat, akan mendorong kemampuan orang dan memberanikan dirinya untuk berbuat sesuatu. Sehubungan dengan itu pemimpin harus mampu memberikan motivasi yang baik kepada anak buahnya (Kartono, 2005: 224).

Motivasi berasal dari bahasa latin "Mavere" yang berarti dorongan atau daya penggerak. Motivasi sering diartikan sebagai daya periggerak yang berasal dari dalam diri seseorang yang disebut oleh Stoner (2008: 134) sebagai karakteristik psikologi manusia yang memberi kontribusi pada tingkat komitmen seseorang.

Selanjutnya Hasibuan (2003: 95) mendefinisikan motivasi sebagai pemberian 
daya penggerak yang melibatkan kegairahan kerja seseorang agar mereka mau bekerjasama, bekerja efektif, dan terintegrasi dengan segala daya upayanya untuk mencapai kepuasan. Hasibuan (2003: 95) menjelaskan bahwa ada faktor yang berasal dari dalam diri seseorang yang mampu bertindak sebagai motivator sehingga seseorang bersedia bekerjasama. Sementara itu Winardi (2002: 6) menjelaskan bahwa yang dimaksud dengan motivasi adalah suatu kekuatan potensial yang ada dalam diri seorang manusia, yang dapat dikembangkan sendiri atau dikembangkan oleh sejumlah kekuatan luar yang pada intinya berkisar pada imbalan moneter dan imbalan non moneter, yang dapat mempengaruhi kinerjanya secara positif atau secara negatif, di mana tergantung pada situasi dan kondisi yang dihadapi orang yang bersangkutan.

Dari beberapa pengertian tersebut ada beberapa unsur dari motivasi, yaitu bahwa motivasi merupakan karakteristik psikologi yang dapat dibangun baik oleh diri sendiri ataupun orang lain dan akan mempengaruhi kinerja pegawai Tata Usaha baik positif maupun negatif tergantung bagaimana pengarahan dan proses pemberiannya. Dalam penelitian ini pihak yang mempunyai pengaruh tersebut adalah pemimpin, yang mana ia memotivasi pegawai Tata Usaha agar bersedia memberikan potensi yang dimiliki secara maksimal.

\section{METODE PENELITIAN}

Penelitian ini menggunakan jenis penelitian deskriptif kualitatif yaitu dengan mempelajari masalah-masalah yang ada, menggambarkan secara sistematis faktual (fakta yang terjadi) dan akurat (dalam pengambilan data). Teknik pengumpulan data dalam penelitian ini adalah wawancara dan studi dokumen. Teknik wawancara yang digunakan peneliti adalah teknik wawancara terpimpin (guided interview), yaitu wawancara yang dilakukan oleh pewawancara dengan membawa sederetan pertanyaan lengkap dan terperinci. Studi dokumentasi dalam penelitian ini dapat berupa rekaman tertulis akan tetapi dapat juga berupa gambar atau benda peninggalan yang berkaitan dengan aktivitas tertentu.

Sesuai dengan tipe penelitian, yaitu deskriptif kualitatif, maka setelah data terkumpul, proses selanjutnya adalah menyederhanakan data yang diperoleh ke dalam bentuk yang mudah dibaca, dipahami dan diinterpretasi yang pada hakikatnya merupakan upaya peneliti untuk mencari jawaban atas permasalahan yang telah dirumuskan. Data yang diperoleh selanjutnya dianalisis secara kualitatif, artinya dari data yang diperoleh dilakukan pemaparan serta 
interpretasi secara mendalam. Data yang ada dianalisis serinci mungkin sehingga

\section{HASIL PENELITIAN DAN \\ PEMBAHASAN}

Berdasarkan hasil wawancara dengan Ibu Ifa Yetriani selaku Pimpinan Madrasah (18 Juli 2016 jam 13.00 WIB) "mengenai komunikasi saya selalu berkomunikasi dengan pegawai Tata Usaha karena hal tersebut sangat penting apalagi menyangkut pelayanan. Komunikasi juga selalu saya lakukan melalui pertemuan-pertemuan rutin antar pegawai Tata Usaha baik itu saat jam kerja maupun di luar jam kerja. Di luar jam kerja saya biasanya makan siang dengan beberapa pegawai Tata Usaha dengan begitu saya bisa berkomunikasi dengan cara yang berbeda, lebih rileks dan santai tanpa ada batasan antara pimpinan dan bawahan. Dengan adanya pertemuan tersebut maka hubungan saya dan pegawai Tata Usaha terjalin dengan baik. Saya juga memberikan kesempatan kepada pegawai Tata Usaha untuk memberikan masukan atau pendapat sehingga mereka juga merasa dilibatkan". Hal ini sesuai dengan yang diungkapkan Brantas (2009: 167) yang menjelaskan keberhasilan suatu komunikasi dinilai dari ketercapaian tujuan komunikasi yang didukung oleh kepercayaan komunikan terhadap komunikator serta keterampilan diharapkan dapat diperoleh kesimpulan yang memadai yang bisa digeneralisasikan.

komunikator berkomunikasi, daya tarik pesan dan kesesuaian pesan dengan kebutuhan komunikan, pengalaman tentang isi pesan antara komunikator dengan komunikan, kemampuan komunikan menafsirkan pesan, tatanan komunikasi yang kondusif, dan sistem penyampaian pesan sesuai dengan indera penerima pesan.

Selanjutnya Wawancara dengan Bapak Pakmal Jumadi selaku kepala Tata Usaha (18 Juli 2016 13.30 WIB) "mengenai komunikasi kami selalu berkomunikasi dengan pimpinan baik secara formal maupun informal, kami juga diberikan kesempatan mengemukakan pendapat dan membicarakan tentang penyusunan rencana strategi apa yang akan digunakan MTs Negeri Koto Baru Solok. Saya juga melakukan komunikasi dengan para staf lain yang ada di kantor ini, karena komunikasi sangatlah penting dalam menunjang pekerjaan masing-masing”.

Selanjutnya wawancara dengan Ibuk Yosi tamaila selaku Operator SAIBA (18 Juli 2016 jam 14.00) mengungkapkan bahwa "pimpinan selalu berkomunikasi dengan kami, baik pada jam kerja maupun diluar jam kerja. Pimpinan juga selalu memberikan kesempatan bicara dan mengemukakan pendapat pada saat rapat rutin ataupun pada saat dalam kondisi informal. Mengenai 
komunikasi, saya juga selalu berkomunikasi dengan pimpinan dengan adanya rapat atau pertemuan tersebut pimpinan selalu menanyakan pendapat kami atau meminta saran. Pimpinan tidak pernah membatasi ruang lingkup komunikasi kita, di mana kita butuh berhubungan langsung dengan pimpinan beliau siap kapan saja".

Terkait dengan pengarahan dan pemberian bimbingan kepada pegawai Tata Usaha berdasarkan hasil wawancara dengan Ibu Ifa Yetriani (19 Juli 2016 jam 14.00 WIB) "dalam hal pemberian bimbingan dan juga pengarahan kepada pegawai Tata Usaha saya selalu memberikan bimbingan dan juga pengarahan dalam menyelesaikan pekerjaaannya. Pengarahan itu biasanya berupa arahan lisan contohnya saya mengontrol secara langsung dan memberikan arahan-arahan yang semestinya dikerjakan oleh pegawai Tata Usaha agar mereka menyelesaikan pekerjaannya dengan baik. Saya juga membimbing pegawai Tata Usaha agar lebih kreatif dan produktif agar mereka bisa maju, kemajuan perusahaan ditentukan oleh kinerja para pegawai Tata Usaha itu sendiri".

Menurut Hasibuan (2003: 22) pengarahan (directing) adalah kegiatan mengarahkan semua karyawan/pegawai Tata Usaha agar mau bekerjasama dan bekerja efektif secara efisien dalam terwujudnya tujuan Madrasah, pegawai tata usaha dan masyarakat. Pengarahan dilakukan oleh pimpinan dengan kepemimpinannya, memerintahkan bawahan agar mau mengerjakan semua tugasnya dengan baik. Sedangkan pengorganisasian adalah kegiatan untuk mengorganisasi semua pegawai tata usaha dengan menetapkan pembagian kerja, hubungan kerja, delegasi wewenang, integrasi dan koordinasinya dalam bagan organisasi (organization chart). Organisasi yang baik membantu tercapainya tujuan secara efektif.

Kemudian situasi kerja yang telah dibentuk pemimpin menurut hasil wawancara dengan Ibu Ifa Yetriani (20 Juli 2016 jam 09.00 WIB) "sebenarnya saya tidak berperan sangat besar di dalam pembentukan situasi kerja di sini, karena memang situasi dan kondisi kerja yang nyaman dan kondusif telah terjalin di kantor ini sebelum saya datang. Mungkin hanya ada penambahan sedikit di sana sini dari saya, penambahan itu pun saya lakukan bukan karena kondisi kerja disini tidak nyaman, yang saya lakukan itu dimaksudkan hanya untuk mendekatkan diri secara personal antara saya dan orang-orang di kantor ini".

Kemudian pemberian pengawasan dan hukuman terhadap pegawai Tata Usaha berdasarkan hasil wawancara dengan Ibu Ifa Yetriani (21 Juli 10.15 WIB) "mengenai 
pengawasan di sini sudah menjadi tugas dan kewajiban saya memberikan pengawasan kepada pegawai Tata Usaha di dalam menyelesaikan pekerjaannya. Saya selalu memberikan hukuman kepada pegawai Tata Usaha yang menyalahi aturan Madrasah. Pengawasan ini biasanya langsung saya lakukan di tempat kerja dan pada saat jam kerja. Selanjutnya mengenai sanksi yang digunakan berupa sanksi peringatan (peringatan tertulis), sanksi administratif (berupa penurunan jabatan)".

Kusnadi (2002:266) mengatakan dalam buktinya kalau pengawasan seperti ini adalah model pengawasan detektif, yaitu pengawasan yang ditujukan untuk mendeteksi atau memantau berbagai kesalahan atau kecurangan secara berkelanjutan atas kinerja yang sedang berlangsung. Ada beberapa keuntungan yang didapat dari sistem ini, yang paling utama adalah kita bisa mengetahui watak yang sebenarnya dari pegawai tata usaha itu sendiri, karena secara psikologis pegawai tata usaha merasa tidak diawasi, sehingga bisa berbuat semaunya, dari sini kita bisa melihat apakah para pegawai tata usaha yang ada sesuai dengan criteria, yang dibutuhkan Madrasah. Walaupun begitu, ada satu kelemahan mendasar dari sistem ini, apalagi jika mempercayakan pengawasan kepada orang lain, karena pimpinan akan mengelahui kinerja pegawai tata usaha bergantung pada laporan-laporan dari orang kepercayaan, hal ini bisa dibilang riskan, dan dengan adanya kemungkinan pimpinan tidak mendapatkan data yang faktual.

Kendala yang dihadapi oleh pemimpin dalam memotivasi menurut hasil wawancara dengan Ibu Ifa Yetriani (22 Juli 2016 jam 09.00 WIB) "memotivasi orang yang memiliki skill akan lebih susah dari pegawai Tata Usaha yang sedang-sedang saja, dan sebaliknya memotivasi pegawai Tata Usaha tetap akan lebih mudah daripada memberi motivasi pada agen-agen di lapangan".

Pemimpin mengatasi masalah dalam memotivasi berdasarkan hasil wawancara dengan Ibu Ifa Yetriani (23 Juli 2016 jam 10.00 WIB) adalah "saya percaya setiap masalah akan bisa diselesaikan dengan baik asal dihadapi dengan kepala dingin dan berusaha mencari solusi terbaik tanpa ada efek negatif terhadap Madrasah dan Pegawai tata usaha, jadi di sini saya juga selalu mencari jalan keluar terbaik dalam setiap masalah yang timbul termasuk kendalakendala dalam pemberian motivasi. Saya selalu berusaha memberikan motivasi yang tepat pada pegawai Tata Usaha saya, dan berharap tidak ada masalah yang akan timbul, dan jikalau harus dihadapkan pada masalah maka saya selalu menyelesaikannya 
dengan kepala dingin dan tidak terburu-buru dalam mengambil keputusan, sebagai contoh masalah yang saya hadapi dalam pemberian motivasi bermacam-macam namun saya mencoba mengurai satu persatu masalahnya dan mencari jalan apa yang bisa dilakukan untuk menyelesaikan masalah tersebut".

Metode motivasi yang digunakan pemimpin untuk hasil maksimal sesuai hasil wawancara dengan Ibu Ifa Yetriani (23 Juli 2016 jam 11.00 WIB) adalah "pemberian motivasi saya tidak selalu berpegang secara toeritis, namun saya lebih mendekatkan diri secara personal dengan para pegawai tata usaha saya sehingga terjalin sebuah hubungan yang berkesinambungan antara semua pegawai di sini. Dengan mengenal lebih dalam kepada para pegawai Tata Usaha, saya akan mengerti karakter dan kepribadian mereka satu persatu sehingga memudahkan saya untuk memberikan motivasi jika saya telah mengenal dan mendalami pribadi masing-masing pegawai tata usaha saya dengan cara yang berbedabeda sesuai dengan sikap dan kepribadian mereka. Sebagai contoh, tidak mungkin saya nnemberikan motivasi secara meledak-ledak kepada pegawai tata usaha yang memiliki karakter pendiam dan sensitive, begitu pula sebaliknya”. Menurut Kartono (2005: 224) motivasi yang jelas, tegas, dan kuat, akan mendorong kemampuan orang, dan memberanikan dirinya untuk berbuat sesuatu. Sehubungan dengan itu pemimpin harus mampu memberikan motivasi yang baik dan benar kepada anak buahnya.

Prosedur/tahap-tahap pemberian motivasi berdasarkan hasil wawancara dengan Ibu Ifa Yetriani (23 Juli 2016 jam 09.00 WIB) adalah "sebetulnya yang saya lakukan bukan dibilang tahap atau prosedur karena memang sebenarnya dalam pemberian motivasi tidaklah susah jika para pegawai tata usaha bersikap proaktif dalam bekerja, jadi saya hanya tinggal memanggil pegawai Tata Usaha keruangan saya dan memberikan suntikan motivasi kepada mereka, terkadang kami juga membicarakan hal lain yang menjadi kesenangan pegawai tata usaha tersebut agar suasana tidak menjadi tegang. Kalau sedang tidak pada jam kerja saya juga memberikan motivasi kepada pegawai tata usaha jika memang diperlukan, dan itu kami lakukan diluar kantor dan pada suasana informal yang mendukung untuk dapat respon yang baik dari pegawai Tata Usaha”.

Djanaid (2004:171) menyebutnya sebagai prinsip-prinsip memotivasi yang meliputi 1) pemimpin harus memahami semua perilaku anak buah; 2) dalam memotivasi bawahan seorang pemimpin harus berorientasi pada latar, karakter bawahan; 3) dalam memotivasi perlu didasarkan bahwa bawahan itu tidak sama. 
Dengan kata lain merangsang seseorang harus berbeda dengan orang lain; 4) motivasi yang berulang-ulang akan tidak efektif; 5) dalam memotivasi bawahan dengan motif tertentu akan memiliki daya dorong yang berbeda; 6) faktor keteladanan besar pengaruhnya dalam memotivasi anak buah; dan 7) dalam memotivasi anak buah harus reelistik, tidak utopis.

Pemberian penghargaan kepada pegawai Tata Usaha menurut hasil wawancara dengan Ibu Ifa Yetriani (23 Juli 2016 jam 11.20 WIB) "saya selalu memberikan penghargaan kepada pegawai tata usaha yang bekerja dengan baik dan memberikan kontribusi yang besar bagi Madrasah, karena dengan diberikannya penghargaan pegawai tata usaha akan semakin termotivasi untuk meningkatkan semangat kerja. Adapun penghargaan itu berupa imbalan (reward), imbalan biasanya diberikan kepada pegawai tata usaha yang sukses dalam melaksanakan tugas, terutama pegawai tata usaha dalam bidang Keuangan”.

Hasibuan (2006: 185) mengemukakan jika kepada karyawan diberikan pengakuan asas sumbangannya terhadap hasil-hasil yang dicapai, maka pegawai Tata Usaha akan merasa dihargai, dan ujung-ujungnya pegawai Tata Usaha akan bekerja lebih keras untuk meningkatkan performa perusahaan. Pemberian penghargaan yang dilakukan oleh pemimpin merupakan hal yang paling penting dalam proses manajemen. Dengan diberikannya penghargaan oleh pemimpin dapat memberikan dorongan atau dapat memotivasi kerja pegawai tata usaha dalam menyelesaikan tugas dengan baik, sehingga perusahaan diuntungkan dengan hasil yang diberikan karyawan begitu juga sebaliknya pegawai Tata Usaha diuntungkan dengan adanya imbalan yang diberikan oleh Madrasah. Jadi, peran pemimpin dalam hal pemberian penghargaan kepada pegawai tata usaha akan membuat pegawai tata usaha dapat termotivasi dalam bekerja.

Umpan balik pegawai Tata Usaha setelah diberi motivasi sesuai hasil wawancara dengan Ibu Ifa Yetriani (23 Juli 201612.30 WIB) "pada dasarnya setiap motivasi yang saya berikan untuk pegawai tata usaha selalu berujung pada diri mereka sendiri keberhasilannya, selain memang ada faktor cara-cara memberikan dorongan itu dari saya tetapi semua itu bergantung dari kemampuan dari setiap pegawai tata usaha untuk menerima dorongan dan menjadikannya sebagai sebuah motivasi membangun untuk memperbaiki kinerja dan performa mereka. Karena dalam kenyataannya ada pegawai tata usaha yang tidak mampu mentransformasi dorongan yang diberikan itu menjadi suatu kritik yang membangun, tetapi para pegawai tata usaha 
saya di sini selalu baik dalam menyikapi motivasi yang saya berikan".

\section{KESIMPULAN}

Berdasarkan hasil penelitian yang telah dilakukan peneliti dapat menyampaikan kesimpulan sebagai berikut: 1) peran pemimpin di MTs Negeri Koto Baru Solok dalam memotivasi pegawai Tata Usaha adalah berkomunikasi, mengarahkan dan memberikan bimbingan, memotivasi, pembentukan situasi kerja, pemberian pengawasan dan hukuman, mengetahui kendala-kendala dalam memotivasi serta cara-cara mengatasi permasalahan yang timbul dalam pemberian motivasi; 2) kendala yang dihadapi pemimpin dalam memotivasi pegawai Tata Usaha yaitu setiap karyawan mempunyai tipe dan karakter yang berbedabeda. Seperti dikatakan juga memotivasi pegawai Tata Usaha yang memiliki skill memang lebih sulit dibanding pegawai Tata Usaha yang biasa-biasa saja, itu dikarenakan tingkat dan pola pikir mereka berbeda antara karyawan yang satu dengan yang lain; dan 3) mengatasi permasalahan dalam memotivasi, seorang pemimpin lebih meningkatkan hubungan personal dengan para pegawai Tata Usaha. Dalam pendekatan ini akan terjalin sebuah hubungan yang berkesinambungan antara semua pegawai tata usaha. Memahami karakter dan kepribadian setiap karyawan akan memudahkan untuk memberikan motivasi.

\section{DAFTAR PUSTAKA}

Brantas. (2009). Dasar-Dasar Manajemen. Bandung: Alfabeta.

Djanaid, Djanalis. (2004). Kepemimpinan Eksekutif: Teori dan Praktik.

Hasibuan, Malayu SP. (2006). Manajemen Dasar, Pengertian Dari Masalah. Jakarta: CV Haji Masagung.

- (2003). Organisasi \& Motivasi: Dasar Peningkatan Produktivitas. Jakarta: Bumi Aksara.

Hersey, Paul. dan Blanchard, Kenneth H. (2008). Manajemen Perilaku Organisasi: Pendayagunaan Sumber Daya Manusia. Jakarta: Erlangga.

Kartono, Kartini. (2005). Psikologi Sosial Untuk Manajemen Perusahaan dan Industri. Jakarta: CV Rajawali.

Kusnadi, (2002). Pengantar Manajemen, Konseptual dan Prilaku. Malang: Unibraw.

Mohyi, Ach. (2006). Teori dan perilaku Organisasi. Malang: UMM Press.

Nawawi, Hadari. (2003). Kepemimpinan Mengefektifkan Organisasi. Yogyakarta: Gajah Mada University Press.

Winardi, J. (2002). Motivasi dan Pemotivasian dalam Manajemen. Jakarta: PT Raja Grafindo Persada. 